\title{
EVALUATION OF RADIOACTIVITY IN MONTENEGRO SOIL USING A STATISTICAL APPROACH
}

\author{
Nevenka M. Antovićc ${ }^{\prime *}$, Nikola R. Svrkota ${ }^{2}$ \\ ${ }^{1}$ University of Montenegro, Faculty of Natural Sciences and Mathematics, Podgorica, Montenegro \\ ${ }^{2}$ Centre for Ecotoxicological Research, Podgorica, Montenegro
}

\begin{abstract}
Surface soil from 47 locations in Montenegro had been previously analyzed for radioactivity due to natural ${ }^{226} \mathrm{Ra},{ }^{232} \mathrm{Th},{ }^{40} \mathrm{~K}$ and man-made ${ }^{137} \mathrm{Cs}$, and showed mean activity concentrations around 41.1, 45.8, 500 and $95.2 \mathrm{~Bq} / \mathrm{kg}$, respectively. Discriminant Analysis used in the present study for the classification, with activity concentrations of radionuclides as independent variables and the Montenegro region (South, Center, North) as a grouping variable, showed $76.6 \%$ of original grouped cases as correctly classified. The radium equivalent activity, external and internal hazard index showed a mean of $142 \mathrm{~Bq} / \mathrm{kg}, 0.39$ and 0.5 , respectively. An average external terrestrial gamma absorbed dose rate was found to be $67.5 \mathrm{nGy} / \mathrm{h}$ - for natural radionuclides only, and $79.3 \mathrm{nGy} / \mathrm{h}$ for natural radionuclides and ${ }^{137 C s}$. The corresponding annual effective dose showed a mean of o.08 mSv and around $0.1 \mathrm{mSv}$, respectively. These hazard indices, together with radionuclide activities, are used in the factor analysis performed with Principal Component Analysis as the extraction method and Varimax with Kaiser Normalization as the rotation method. Two components were extracted. The first one loaded basically on ${ }^{232} \mathrm{Th}$ and ${ }^{226} \mathrm{Ra}$ activity explained $\sim 80.6 \%$ of the total variance, while the second component explaining $\sim 2.2 \%$ of the total variance is found to be strongly correlated with ${ }^{137} \mathrm{Cs}$ and ${ }^{40} \mathrm{~K}$ activity.
\end{abstract}

Keywords: soil, Montenegro, radionuclides, Discriminant Analysis, PCA

\section{INTRODUCTION}

Montenegro is a Balkan country with a territory of $13812 \mathrm{~km}^{2}$ and a population of around 620 ooo according to the Census in 2011 [1]. A geographical distribution of the municipalities in Montenegro is:

- South, i.e. South Adriatic coastal region (Ulcinj, Bar, Budva, Tivat, Kotor, Herceg Novi),

- Center (Cetinje, Podgorica, Danilovgrad, Nikšić),

○ North (Plužine, Šavnik, Žabljak, Pljevlja, Bijelo Polje, Berane, Rožaje, Andrijevica, Plav, Mojkovac, Kolašin).

Podgorica and Nikšić are the largest municipalities - by the population and land area, respectively.

Radionuclides of terrestrial origin and their activity concentrations in the soil of Montenegro have been previously analyzed in the frame of wider studies (e.g. [2-4]), such as external exposure by gamma radiation from nuclides in the series of ${ }^{238} \mathrm{U},{ }^{232} \mathrm{Th}$, as well as ${ }^{40} \mathrm{~K}$. The man-made ${ }^{137 \mathrm{Cs}}$ of the Chernobyl origin [5] was also measured in soil samples and then analyzed from various aspects.

It is known [6] that activity concentrations of $4^{\circ} \mathrm{K}$ in soil in the world have medians in the range from 140 to $850 \mathrm{~Bq} / \mathrm{kg}$, with an arithmetic mean of $400 \mathrm{~Bq} / \mathrm{kg}$ and population-weighted mean $420 \mathrm{~Bq} / \mathrm{kg}$, but also that ${ }^{238} \mathrm{U}$ activity concentrations in soil worldwide showed medians in the range from 16 to $110 \mathrm{~Bq} / \mathrm{kg}$, with a mean of $35 \mathrm{~Bq} / \mathrm{kg}$, and population-weighted mean 33 $\mathrm{Bq} / \mathrm{kg}$. In the case of ${ }^{226} \mathrm{Ra}$ medians are from 17 to 60 $\mathrm{Bq} / \mathrm{kg}$, with a mean of $35 \mathrm{~Bq} / \mathrm{kg}$, and populationweighted mean $32 \mathrm{~Bq} / \mathrm{kg}$, and ${ }^{232} \mathrm{Th}$ - from 11 to 64 $\mathrm{Bq} / \mathrm{kg}$, with means of $30 \mathrm{~Bq} / \mathrm{kg}$ and $45 \mathrm{~Bq} / \mathrm{kg}$, respectively [6].

If public exposure to natural radiation is considered, according to the UNSCEAR 2008 report [7], average annual effective dose coming from external terrestrial radiation outdoors is $0.07 \mathrm{mSv}$ (indoor $0.41 \mathrm{mSv}$, and in total from external terrestrial radiation $-0.48 \mathrm{mSv}$ ) which is less than $3 \%$ of the total average annual effective dose from natural sources (2.4 $\mathrm{mSv})$.

The present study has been aimed to evaluate for the first time radioactivity in soils of Montenegro using a statistical approach. Therefore, some of the already published data related to activity concentrations of ${ }^{226} \mathrm{Ra},{ }^{232} \mathrm{Th},{ }^{40} \mathrm{~K}$ and ${ }^{137} \mathrm{Cs}$ in surface soils of the three country regions (South, Center, North), as well as a few new ones, are used in the analysis.

\section{MATERIAL AND METHODS}

A standard procedure for the sampling [8] had been applied previously to take soil samples: 47 in total, 10 on the South, 17 in the Central region, and 20 on the North, covering all the municipalities previously mentioned (with more than one soil sample from Bar, Budva, Kotor, Podgorica, Nikšić and Mojkovac).

\footnotetext{
"antovicn@yahoo.com
} 
The top of uncultivated soil (up to $5 \mathrm{~cm}$ ) had been sampled from an area of $25 \mathrm{~cm}$ x $25 \mathrm{~cm}$. The samples were dried at room temperature, passed through the $2 \mathrm{~mm}$ sieves, placed in the 0.5 or $1 \mathrm{~L}$ Marinelli beakers and kept for more than 38 days at airtight conditions (with no ${ }^{222} \mathrm{Rn}$ emanation), to allow radioactive equilibrium between ${ }^{226} \mathrm{Ra}$ and its decay products.

Gamma spectrometry was carried out in the Centre for Ecotoxicological Research in Podgorica, using the coaxial HPGe spectrometers ORTEC GEM-40190 (relative efficiency: 40\%) and ORTEC GEM-30185-S (relative efficiency: $35 \%$ ). The spectrometers were calibrated in the standard way using 0.5 and $1 \mathrm{~L}$ Marinelli beaker calibration standards (mixtures of gamma-emitting radionuclides), as well as the software Gamma Vision 32 [9].

The activity concentrations of ${ }^{226} \mathrm{Ra}$ in soil samples were determined using photopeaks created by gamma rays emitted after decays of its daughters - at the energies of $295 \mathrm{keV}, 352 \mathrm{keV}, 609 \mathrm{keV}, 1120.2 \mathrm{keV}$ and $1764.4 \mathrm{keV} ;{ }^{232} \mathrm{Th} /{ }^{228} \mathrm{Ac}-338 \mathrm{keV}$ and $911 \mathrm{keV},{ }^{40} \mathrm{~K}-$ $1461 \mathrm{keV}$, and ${ }^{137 \mathrm{Cs}}-662 \mathrm{keV}$ [10]. The standard procedure was applied, and radionuclide activity concentrations were determined using the total net counts (after subtracting corresponding background) under the selected photopeaks, photoefficiency, $\gamma$-ray relative intensity, as well as weight of the samples.

Measured activity concentrations ( $\mathrm{A}_{c}\left({ }^{226} \mathrm{Ra}\right)$, $\left.\mathrm{A}_{c}\left({ }^{232} \mathrm{Th}\right), \mathrm{A}_{c}\left({ }^{40} \mathrm{~K}\right), \quad \mathrm{A}_{\mathrm{c}}\left({ }^{137} \mathrm{Cs}\right)\right)$ were then used to calculate hazard indices: radium equivalent activity $\left(\mathrm{Ra}_{\mathrm{eq}}\right)$, external hazard index $\left(\mathrm{H}_{\mathrm{ex}}\right)$, internal hazard index $\left(\mathrm{H}_{\text {in }}\right)$, activity concentration index (I) - due to natural radionuclides ${ }^{226} \mathrm{Ra},{ }^{232} \mathrm{Th}$ and ${ }^{40} \mathrm{~K}$, as well as gamma absorbed dose rate in air at $1 \mathrm{~m}$ above the ground level (D) and corresponding annual effective dose (E). These two doses are estimated for natural radionuclides ( $\mathrm{D}_{\text {natural }}$ and $\mathrm{E}_{\text {natural }}$ ), but also for natural radionuclides and ${ }^{137} \mathrm{Cs}\left(\mathrm{D}_{\text {(natural }+\mathrm{Cs})}\right.$ and $\left.\mathrm{E}_{(\text {natural }+\mathrm{Cs})}\right)$.

The radium equivalent activity (expressed in $\mathrm{Bq} / \mathrm{kg}$; with upper level of $370 \mathrm{~Bq} / \mathrm{kg}$ in samples of building materials) can be calculated using [11]

$\mathrm{Ra}_{\mathrm{eq}}=\mathrm{A}_{\mathrm{c}}\left({ }^{226} \mathrm{Ra}\right)+1.43 \cdot \mathrm{A}_{\mathrm{c}}\left({ }^{232} \mathrm{Th}\right)+0.077 \cdot \mathrm{A}_{\mathrm{c}}\left({ }^{\circ} \mathrm{K}\right) ;$

the external hazard index (with unity as upper level; corresponding to the upper limit of radium equivalent activity)

$\mathrm{H}_{\mathrm{ex}}=\mathrm{A}_{\mathrm{c}}\left({ }^{226} \mathrm{Ra}\right) / 37 \mathrm{O}+\mathrm{A}_{\mathrm{c}}\left({ }^{232} \mathrm{Th}\right) / 259+\mathrm{A}_{\mathrm{c}}\left({ }^{\circ} \mathrm{K}\right) / 4810,(2)$

the internal hazard index (hazardous internal exposure to radon and its short-lived daughters)

$\mathrm{H}_{\text {in }}=\mathrm{A}_{\mathrm{c}}\left({ }^{226} \mathrm{Ra}\right) / 185+\mathrm{A}_{\mathrm{c}}\left({ }^{232} \mathrm{Th}\right) / 259+\mathrm{A}_{\mathrm{c}}\left(4^{40} \mathrm{~K}\right) / 4810$, (3)

which should also be less than unity for the radiation risk to be negligible.

The activity concentration index is defined as [12]

$\mathrm{I}=\mathrm{A}_{\mathrm{c}}\left({ }^{226} \mathrm{Ra}\right) / 300+\mathrm{A}_{\mathrm{c}}\left({ }^{232} \mathrm{Th}\right) / 200+\mathrm{A}_{\mathrm{c}}\left(4^{40} \mathrm{~K}\right) / 3000$, (4)

and it applies to the building material, in excess of typical external outdoor exposure, and its value of 1 relates to the gamma radiation dose from building materials, i.e. its reference level of $1 \mathrm{mSv}$ per year.

The gamma absorbed dose rate in the air at $1 \mathrm{~m}$ above the ground level was calculated (in $\mathrm{nGy} / \mathrm{h}$ ) using the equation:

$\mathrm{D}=\mathrm{A}_{\mathrm{c}}\left({ }^{226} \mathrm{Ra}\right) \cdot 0.462+\mathrm{A}_{\mathrm{c}}\left({ }^{232} \mathrm{Th}\right) \cdot 0.604+\mathrm{A}_{\mathrm{c}}\left({ }^{40} \mathrm{~K}\right) \cdot 0.0417$, where $0.462,0.604$ and $0.0417 \mathrm{nGy} / \mathrm{h}$ per $\mathrm{Bq} / \mathrm{kg}$ are corresponding dose coefficients [6]. In order to obtain $\mathrm{D}_{\text {(natural }+\mathrm{Cs})}$, i.e. evaluate the same absorbed dose rate

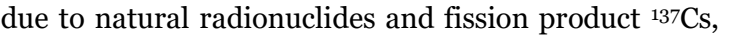

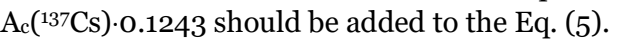

The corresponding annual effective dose (in Sv) was estimated by

$\mathrm{E}=\mathrm{D} \cdot 8760 \cdot 0.2 \cdot \mathrm{e}$,

where $\mathrm{D}$ is dose rate (Eq. 5), e is the dose conversion factor (0.7 Sv/Gy [6]), while numerical values stand for the outdoor occupancy factor (0.2) and number of hours in year $(8760 \mathrm{~h} / \mathrm{y})$.

The software IBM SPSS Statistics [13] was used for statistical analysis of all the data. In addition to frequencies (descriptive statistics), comparing means and testing Pearson correlations, Discriminant Analysis (linear discriminant function analysis) is used for the classification - with activity concentrations of radionuclides as independent variables and Montenegro region (South, Center, North) as grouping variable. This analysis is a multivariate test of differences among groups, and it is used to predict memberships in different (mutually exclusive) groups. The factor analysis was also performed with Principal Component Analysis as the extraction method and Varimax with Kaiser Normalization as the rotation method.

\section{RESULTS AND DISCUSSION}

The results of descriptive statistics for all the indices are given in Table 1 , with frequencies for ${ }^{40} \mathrm{~K}$ and ${ }^{232} \mathrm{Th}$ activity concentrations shown in Fig. 1 as an illustration.

Skewness and kurtosis values in Table 1 show that distribution of all the indices more or less deviates from the normal distribution. Skewness is the measure of asymmetry (there is no skew in the normal distribution; positive skewness means that the distribution is skewed to the right and negative - to the left), and kurtosis also characterizes distribution shape and symmetry (equal to zero in the normal distribution; positive value means distribution more peaked than the normal one). The standard error of skewness was 0.347, while that of kurtosis: 0.681 .

Activity concentrations of natural radionuclides in soils of Montenegro showed averages higher than those characterizing the world as a whole [6].

At the same time, activity concentrations of ${ }^{226} \mathrm{Ra}$ and ${ }^{232} \mathrm{Th}$ showed a statistically significant positive correlation, with Pearson correlation coefficient $\mathrm{r}=0.868$ and $\mathrm{Sig}$. value (2-tailed) 0.000 (correlation is significant at the level of 0.01).

Positive correlations, but not statistically significant, were found between ${ }^{226} \mathrm{Ra}$ and ${ }^{137 \mathrm{Cs} \text { activity }}$ concentrations ( $\mathrm{r}=0.252$ and Sig. 0.087), ${ }^{232} \mathrm{Th}$ and ${ }^{137} \mathrm{Cs}$ ( $\mathrm{r}=0.170$ and Sig. 0.253$),{ }^{232} \mathrm{Th}$ and ${ }^{\circ} \mathrm{K}(\mathrm{r}=0.212$ and Sig. 0.153). Negative correlations, not statistically significant as well, were found between activity concentrations of ${ }^{4} \mathrm{~K}$ and ${ }^{137} \mathrm{Cs}(\mathrm{r}=-0.273$ and Sig. 0.063), ${ }^{226} \mathrm{Ra}$ and ${ }^{40} \mathrm{~K}(\mathrm{r}=-0.011$ and Sig. 0.940). 
Table 1. Results - descriptive statistics

\begin{tabular}{|c|c|c|}
\hline & ${ }^{137 \mathrm{Cs}, \mathrm{Bq} / \mathrm{kg}}$ & ${ }^{40} \mathrm{~K}, \mathrm{~Bq} / \mathrm{kg}$ \\
\hline Mean & 95.2 & 499.8 \\
\hline Std. error of mean & 15.7 & 20.8 \\
\hline Min-Max & $1.3-476$ & $245-753$ \\
\hline Range & 474.7 & 508 \\
\hline Median & 62.4 & 491 \\
\hline Std. deviation & 107.4 & 142.5 \\
\hline Variance & 11527 & 20311 \\
\hline Skewness & 2.021 & -0.040 \\
\hline \multirow[t]{2}{*}{ Kurtosis } & 4.174 & -1.146 \\
\hline & ${ }^{226} \mathrm{Ra}, \mathrm{Bq} / \mathrm{kg}$ & ${ }^{232} \mathrm{Th}, \mathrm{Bq} / \mathrm{kg}$ \\
\hline Mean & 41.1 & 45.8 \\
\hline Std. error of mean & 5.44 & 2.31 \\
\hline Min-Max & $11-216$ & $18.2-107$ \\
\hline Range & 205 & 88.8 \\
\hline Median & 29 & 43.7 \\
\hline Std. deviation & 37.27 & 15.86 \\
\hline Variance & 1389 & 251.4 \\
\hline Skewness & 3.18 & 1.479 \\
\hline \multirow[t]{2}{*}{ Kurtosis } & 11.2 & 4.009 \\
\hline & Raeq, Bq/kg & $\mathrm{H}_{\mathrm{ex}}$ \\
\hline Mean & 141.6 & 0.392 \\
\hline Std. error of mean & 8.696 & 0.0236 \\
\hline Min-Max & $56.8-403$ & $0.159-1.099$ \\
\hline Range & 346.2 & 0.9404 \\
\hline Median & 132 & 0.3673 \\
\hline Std. deviation & 59.62 & 0.1618 \\
\hline Variance & 3554 & 0.026 \\
\hline Skewness & 2.455 & 2.424 \\
\hline \multirow[t]{2}{*}{ Kurtosis } & 8.147 & 8.043 \\
\hline & $\mathrm{H}_{\text {in }}$ & I \\
\hline Mean & 0.503 & 0.532 \\
\hline Std. error of mean & 0.0378 & 0.030 \\
\hline Min-Max & $0.188-1.683$ & $0.222-1.419$ \\
\hline Range & 1.494 & 1.197 \\
\hline Median & 0.446 & 0.504 \\
\hline Std. deviation & 0.259 & 0.206 \\
\hline Variance & 0.067 & 0.043 \\
\hline Skewness & 2.828 & 2.276 \\
\hline \multirow[t]{2}{*}{ Kurtosis } & 9.710 & 7.461 \\
\hline & Dnatural, $\mathrm{nGy} / \mathrm{h}$ & Enatural, $\mathrm{mSv}$ \\
\hline Mean & 67.5 & 0.0828 \\
\hline Std. error of mean & 3.945 & 0.00484 \\
\hline Min-Max & $27.8-185$ & $0.034-0.227$ \\
\hline Range & 157 & 0.1927 \\
\hline Median & 63.5 & 0.0779 \\
\hline Std. deviation & 27.05 & 0.0332 \\
\hline Variance & 731.6 & 0.001 \\
\hline Skewness & 2.370 & 2.370 \\
\hline \multirow[t]{2}{*}{ Kurtosis } & 7.837 & 7.839 \\
\hline & $\mathrm{D}_{\text {(natural+Cs) }}, \mathrm{nGy} / \mathrm{h}$ & $\mathrm{E}_{(\text {natural+Cs) }}, \mathrm{mSv}$ \\
\hline Mean & 79.3 & 0.097 \\
\hline Std. error of mean & 4.67 & 0.0057 \\
\hline Min-Max & 28.1-195 & $0.034-0.239$ \\
\hline Range & 167.07 & 0.2049 \\
\hline Median & 71.907 & 0.0882 \\
\hline Std. deviation & 32.027 & 0.0393 \\
\hline Variance & 1025.7 & 0.002 \\
\hline $\begin{array}{r}\text { Skewness } \\
\text { Kurtosis }\end{array}$ & 1.753 & $\begin{array}{l}1.753 \\
2.08 ?\end{array}$ \\
\hline Kurtosis & 3.980 & 3.982 \\
\hline
\end{tabular}

Mean values of the ${ }^{137} \mathrm{Cs},{ }^{40} \mathrm{~K},{ }^{226} \mathrm{Ra}$ and ${ }^{232} \mathrm{Th}$ activity concentrations in the South region were found to be around $36.4,445,38.3$ and $38.4 \mathrm{~Bq} / \mathrm{kg}$, respectively, in the Center - 135, 453, 57 and 53.7 $\mathrm{Bq} / \mathrm{kg}$, respectively; and in the North $-91,567,29$ and 42.7 Bq/kg, respectively.
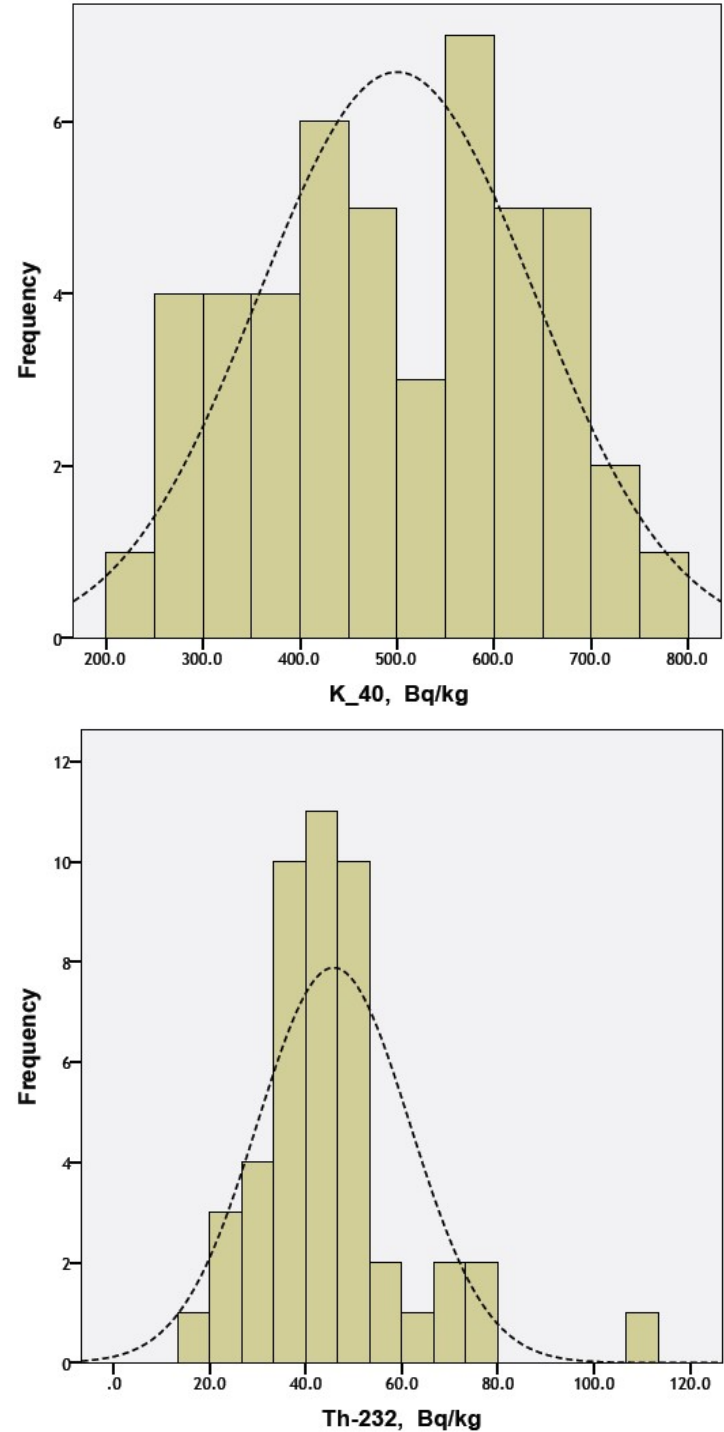

Figure 1. Frequency distribution of $4^{\circ} \mathrm{K}$ and ${ }^{232} \mathrm{Th}$ activity concentrations in soils - fitted by the normal distribution

In the view of geology, the South as a region belongs to the Adriatic-Ionian and Budva-Cukali geotectonic zones [14, 15]. The first one, AdriaticIonian, has geological structure consisting of Upper Cretaceous calcareous sediments, Middle Eocene foraminifer limestone and flysch, Upper Eocene flysch sediments, Middle Miocene and Quaternary sediments. The second one, Budva-Cukali, has geological structure consisting of Triassic, Jurassic, Cretaceous, Paleogene and Quaternary calcareous, eruptive and clastic rocks.

The Central region is characterized by the occurrence of bauxite formations and basically belongs to the High Karst geotectonic zone dominantly composed of Mesozoic carbonate sediments, Triassic volcanic rocks, Paleogene flysch sediments, Quaternary sediments [15].

The fourth geotectonic zone recognized in Montenegro is known as the Durmitor Tectonic Unit and encompasses the North region. Its geological structure consists of clastites (Paleozoic and Lower Triassic), carbonates (Triassic and Jurassic), but also 
volcanic rocks and clastites (Middle Triassic and Upper Jurassic), as well as sediments (Neogene and Quaternary) [15].

Comparing means by the One-way Analysis of Variance (ANOVA), with the region as a factor and radionuclide activity concentration as the dependent variable, showed that the ANOVA is significant (Sig. value $<0.05$ ) for ${ }^{40} \mathrm{~K}$ (Sig. 0.016) and ${ }^{232} \mathrm{Th}$ (Sig. 0.024),

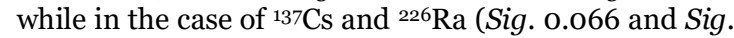
o.069) it is not. To determine which regions differ significantly in the mean activity concentrations, multiple comparisons were carried out using the LSD (Least Significant Difference) post hoc tests (equal variances assumed). Results of multiple comparisons, together with the lower and upper bound of the 95\% confidence interval, are mean differences, standard errors and Sig. values. The mean differences which were found to be significant at the 0.05 level are given in Table 2. It should be noted that the same differences (but negative) are found when changing the position of the region (from $\mathrm{j}$ to $\mathrm{i}$ ). Therefore, for example, the

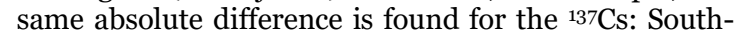
Center (-98.3395).

Table 2. Multiple comparisons - significant mean differences

\begin{tabular}{|c|c|c|c|c|c|}
\hline & $\begin{array}{c}\text { Region } \\
\text { (i) }\end{array}$ & $\begin{array}{c}\text { Region } \\
\text { (j) }\end{array}$ & $\begin{array}{c}\text { Mean } \\
\text { difference } \\
\text { (i-j) }\end{array}$ & $\begin{array}{c}\text { Standar } \\
\text { d error }\end{array}$ & Sig. \\
\hline${ }^{137 \mathrm{Cs}}$ & Center & South & 98.3395 & 41.1334 & 0.021 \\
\hline \multirow{2}{*}{${ }^{40} \mathrm{~K}$} & \multirow{2}{*}{ North } & Center & 114.6353 & 43.7794 & 0.012 \\
\cline { 3 - 6 } & South & 122.7000 & 51.3989 & 0.021 \\
\hline${ }^{226} \mathrm{Ra}$ & \multirow{2}{*}{ Center } & North & 28.0309 & 11.8285 & 0.022 \\
\hline \multirow{2}{*}{${ }^{232} \mathrm{Th}$} & \multirow{2}{*}{ Center } & South & 15.2853 & 5.9344 & 0.013 \\
\cline { 3 - 6 } & North & 11.0803 & 4.9122 & 0.029 \\
\hline
\end{tabular}

Discriminant Analysis of the radionuclide activity concentrations included:

statistics - descriptive (means, univariate ANOVAs i Box's $M$ ),

function coefficients (Fisher's and unstandardized),

within-groups correlation matrix, and classification - compute from group sizes (and all groups equal as another possibility) for prior probabilities,

within-groups covariance matrix, with summary table and separate- and combined-groups plots;

as well as saving predicted group membership, discriminant score, probabilities of group membership.

It showed results as follows.

Results of the univariate ANOVA test (comparing means for each group and each variable to test the significance of differences among them) are presented in Table 3. It is known that a smaller value of Wilks's lambda indicates more importance of the independent variable to the discriminant function. Here, ${ }^{40} \mathrm{~K}$ and ${ }^{232} \mathrm{Th}$ differ significantly (as mentioned previously) for the groups (regions).

Log determinants obtained as results of the Box's M test (comparing the group covariance matrices) are: 26.921 for the South, 30.217 - Center, 24.604 - North, 29.740 - pooled within-groups, showing that the Center covariance matrix differs more, and that there 93 are deviations from the null hypothesis of equal population covariance matrices (in such a case the determinants are relatively equal). This is confirmed by the Box's M of 115.34 and Sig. value 0.000 which means that considered data differ significantly from multivariate normality.

Table 3. Tests of group means equality

\begin{tabular}{|c|c|c|}
\hline & Wilks' lambda & Sig. \\
\hline${ }^{137 \mathrm{Cs}, \mathrm{Bq} / \mathrm{kg}}$ & 0.884 & 0.066 \\
\hline${ }^{40} \mathrm{~K}, \mathrm{~Bq} / \mathrm{kg}$ & 0.829 & 0.016 \\
\hline${ }^{226} \mathrm{Ra}, \mathrm{Bq} / \mathrm{kg}$ & 0.885 & 0.069 \\
\hline $232 \mathrm{Th}, \mathrm{Bq} / \mathrm{kg}$ & 0.844 & 0.024 \\
\hline
\end{tabular}

A summary of canonical discriminant functions is given in Table 4 with eigenvalues indicating percentage of the variance explained (stronger function has higher eigenvalue). It also contains Wilks' lambda, whose maximal value of 1 appears when considered group means are equal, as small values point out the difference among group means (and variance within groups - small in comparison to the total variability). Based on this value it can be concluded how well functions distribute cases into groups. It is clear that in this case the group means differ significantly (Sig. $<0.05)$.

Table 4. Eigenvalues and Wilks' lambda

\begin{tabular}{|c|c|c|c|}
\hline \multicolumn{4}{|c|}{ Eigenvalues } \\
\hline Function & Eigenvalue & $\begin{array}{c}\% \\
\text { of variance }\end{array}$ & $\begin{array}{c}\text { Canon. } \\
\text { correl. }\end{array}$ \\
\hline 1 & 0.464 & 55.3 & 0.563 \\
\hline 2 & 0.375 & 44.7 & 0.522 \\
\hline \multicolumn{4}{|c|}{ Wilks' lambda } \\
\hline $\begin{array}{c}\text { Test of } \\
\text { functions }\end{array}$ & $\begin{array}{c}\text { Wilks' } \\
\text { lambda }\end{array}$ & $\chi^{2}$ & Sig. \\
\hline through 2 & 0.496 & 29.759 & 0.000 \\
\hline 2 & 0.727 & 13.549 & 0.004 \\
\hline
\end{tabular}

The canonical discriminant function coefficients (standardized - indicating an importance of the radionuclide activity concentrations in predicting variable which is the dependent one here, and unstandardized - scores related to the independent variables) are given in Table 5. Higher (absolute) values of the standardized coefficient mean greater variable discriminating ability $\left({ }^{232} \mathrm{Th}\right.$ for function 1 , and ${ }^{\circ} \mathrm{K}$ for function 2 ).

Table 5. The canonical discriminant function coefficients

\begin{tabular}{|c|c|c|}
\hline & \multicolumn{2}{|c|}{ Standardized } \\
\hline & Function 1 & Function 2 \\
\hline${ }^{137} \mathrm{Cs}, \mathrm{Bq} / \mathrm{kg}$ & 0.592 & 0.496 \\
\hline${ }^{40} \mathrm{~K}, \mathrm{~Bq} / \mathrm{kg}$ & -0.370 & 0.914 \\
\hline${ }^{226} \mathrm{Ra}, \mathrm{Bq} / \mathrm{kg}$ & -1.338 & -0.807 \\
\hline${ }^{232} \mathrm{Th}, \mathrm{Bq} / \mathrm{kg}$ & 1.872 & 0.205 \\
\hline & \multicolumn{2}{|c|}{ Unstandardized } \\
\hline & Function 1 & Function 2 \\
\hline & 0.006 & 0.005 \\
\hline${ }^{137} \mathrm{Cs}, \mathrm{Bq} / \mathrm{kg}$ & -0.003 & 0.007 \\
\hline${ }^{40} \mathrm{~K}, \mathrm{~Bq} / \mathrm{kg}$ & -0.037 & -0.022 \\
\hline${ }^{226} \mathrm{Ra}, \mathrm{Bq} / \mathrm{kg}$ & 0.126 & 0.014 \\
\hline${ }^{232} \mathrm{Th}, \mathrm{Bq} / \mathrm{kg}$ & &
\end{tabular}


Unstandardized canonical discriminant functions evaluated at group means, i.e. functions at group centroids showing average discriminant score for members in three groups, were found to be

for the South

$$
\text { function 1: -1.000, function 2: }-0.701 \text {; }
$$

for the Center

function 1: 0.766, function 2: -0.382 ;

for the North

function 1: -0.151 , function 2: 0.675 .

Classification coefficients, i.e. Fisher's linear discriminant functions, for radionuclide activity concentration in top soil in the South, Center and North of Montenegro are

${ }^{137} \mathrm{Cs}$ : 0.017, 0.029 and 0.029, respectively,

${ }^{40} \mathrm{~K}$ : $0.020,0.017$ and 0.027 , respectively,

${ }^{226} \mathrm{Ra}:-0.119,-0.192$ and -0.181 , respectively,

${ }^{232} \mathrm{Th}: 0.358,0.585$ and 0.484 , respectively.

Finally, the summary results are presented in Fig. 2 , with pretty well-separated centroids of groups. The classification results showed that $76.6 \%$ of original grouped cases are correctly classified. As it is expected, a classification with prior probability -all groups equal- gave a smaller percentage of original grouped cases as correctly classified (68.1\%).

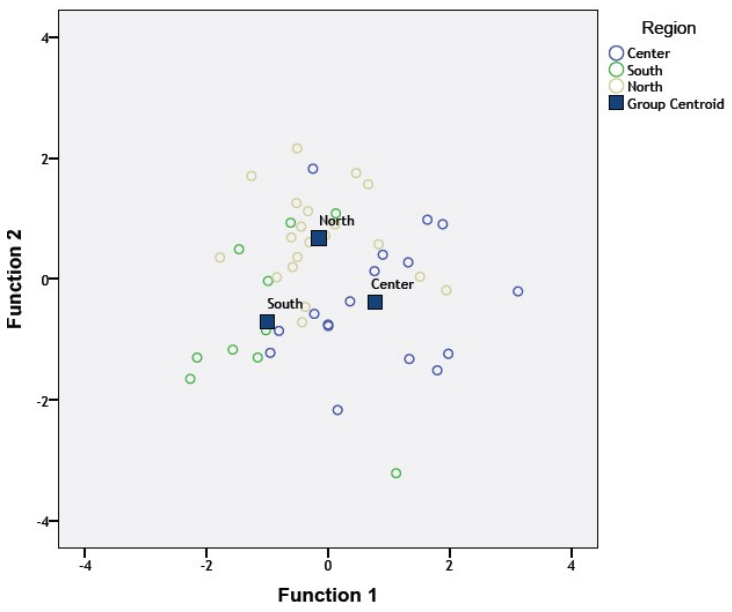

Figure 2. Separation of soil samples from three regions in Montenegro by two discriminant functions

The factor analysis was also performed for all the indices, with Principal Component Analysis as the extraction method (based on eigenvalues greater than 1) and Varimax with Kaiser Normalization as the rotation method. The analysis was based on

correlation matrix (determinant $=0.000$, not positive definite),

communalities (initial, extraction),

data about total variance explained,

component matrix with 2 components extracted,

reproduced correlations and residuals (computed between observed and reproduced correlations;

with 10 (15\%) nonredundant residuals with absolute values greater than 0.05), as well as rotated component matrix given in Table 6 (rotation converged in 3 iterations).

The component score coefficient matrix is given in Table 7, while Fig. 3 shows the component plot in the rotated space.

Table 6. Rotated component matrix

\begin{tabular}{|c|c|c|}
\hline & \multicolumn{2}{|c|}{ Component } \\
\hline Variable & 1 & 2 \\
\hline Raeq, Bq/kg & 0.996 & -0.061 \\
$\mathrm{H}_{\text {ex }}$ & 0.996 & -0.072 \\
Enatural, $\mathrm{mSv}_{\mathrm{I}}$ & 0.995 & -0.096 \\
$\mathrm{D}_{\text {natural, }} \mathrm{nGy} / \mathrm{h}$ & 0.995 & -0.096 \\
$\mathrm{H}$ & 0.994 & -0.110 \\
$\mathrm{H}_{\text {in }}$ & 0.991 & 0.006 \\
${ }^{232} \mathrm{Th}, \mathrm{Bq} / \mathrm{kg}$ & 0.955 & -0.056 \\
${ }^{226} \mathrm{Ra}, \mathrm{Bq} / \mathrm{kg}$ & 0.950 & 0.133 \\
$\mathrm{D}_{\text {(natural+Cs) }}, \mathrm{nGy} / \mathrm{h}$ & 0.947 & 0.274 \\
$\mathrm{E}_{(\text {natural+Cs) }} \mathrm{mSv}$ & 0.947 & 0.274 \\
${ }_{137 \mathrm{Cs}, \mathrm{Bq} / \mathrm{kg}}$ & 0.257 & 0.852 \\
$40 \mathrm{~K}, \mathrm{~Bq} / \mathrm{kg}$ & 0.236 & -0.732 \\
\hline
\end{tabular}

The obtained data showed that there were two initial eigenvalues and extraction sums of squared loadings $>1$ (component 1: 9.670 and component 2: 1.467) explaining 80.583 and $12.226 \%$ of the variance (92.809\% in total). The first component loaded basically on ${ }^{232} \mathrm{Th}$ and ${ }^{226} \mathrm{Ra}$ activity (in Table 6: 0.955 and 0.950 , respectively) explained around $80.6 \%$ of the total variance. The second one, explaining around $12.2 \%$ of the total variance, is found to be strongly correlated with ${ }^{137} \mathrm{Cs}$ and ${ }^{40} \mathrm{~K}$ activity (in Table 6: 0.852 and -0.732 , respectively), as it can also be seen from Fig. 3 .

Table 7. Component score coefficient matrix

\begin{tabular}{|c|c|c|}
\hline & \multicolumn{2}{|c|}{ Component } \\
\hline Variable & 1 & 2 \\
\hline $137 \mathrm{Cs}, \mathrm{Bq} / \mathrm{kg}$ & 0.014 & 0.577 \\
$40 \mathrm{~K}, \mathrm{~Bq} / \mathrm{kg}$ & 0.035 & -0.502 \\
$226 \mathrm{Ra}, \mathrm{Bq} / \mathrm{kg}$ & 0.097 & 0.077 \\
$232 \mathrm{Th}, \mathrm{Bq} / \mathrm{kg}$ & 0.100 & -0.052 \\
$\mathrm{Ra}$ eq, Bq/kg & 0.104 & -0.056 \\
$\mathrm{H}$ ex & 0.104 & -0.064 \\
$\mathrm{H}$ in & 0.103 & -0.010 \\
$\mathrm{I}$ & 0.105 & -0.090 \\
$\mathrm{D}_{\text {natural }}, \mathrm{nGy} / \mathrm{h}$ & 0.105 & -0.080 \\
Enatural, $\mathrm{mSv}$ & 0.105 & -0.080 \\
$\mathrm{D}_{\text {(natural+Cs), } \mathrm{nGy} / \mathrm{h}}$ & 0.094 & 0.172 \\
$\mathrm{E}_{\text {(natural }+\mathrm{Cs}), \mathrm{mSv}}$ & 0.094 & 0.173 \\
\hline
\end{tabular}

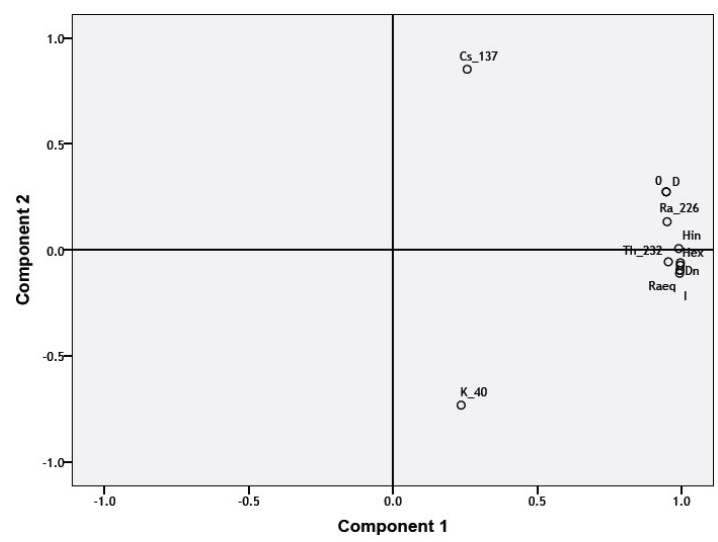

Figure 3. Plot in rotated space: component $1(\sim 80.6 \%)$ and component $2(\sim 12.2 \%)$ 
N. M. Antović, N. R. Svrkota, Evaluation of radioactivity..., RAP Conf. Proc., vol. 4, 2019, 90-95

\section{CONCLUSIONS}

Radionuclide activity concentrations in soils of Montenegro and radiation hazard indices inferred from those concentrations have been evaluated for the first time using a statistical approach.

A statistically significant positive correlation (Pearson correlation coefficient o.868) is found between ${ }^{226} \mathrm{Ra}$ and ${ }^{232} \mathrm{Th}$ activity concentrations in soil samples from 47 locations in Montenegro, 10 on the South, 17 in the Central region, and 20 on the North.

Statistically significant mean differences are found

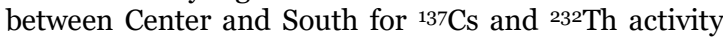
concentration, Center and North for ${ }^{40} \mathrm{~K},{ }^{226} \mathrm{Ra}$ and ${ }^{232} \mathrm{Th}$, and North and South for ${ }^{40} \mathrm{~K}$ activity concentration.

The highest average ${ }^{40} \mathrm{~K}$ activity concentration ( 567

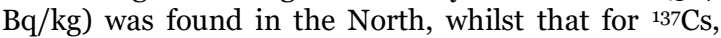
${ }^{226} \mathrm{Ra}$ and ${ }^{232} \mathrm{Th}$ - in the Center. Average ${ }^{226} \mathrm{Ra}$ and ${ }^{232} \mathrm{Th}$ activity concentrations in the Central region ( 57 and $53.7 \mathrm{~Bq} / \mathrm{kg}$, respectively), higher than the South, North and worldwide averages, could be explained by the region geology. The Central region in Montenegro is characterized by the occurrence of bauxite formations, and it is a limestone and High Karst area with volcanic rocks and flysch sediments. Therefore, somewhat higher ${ }^{226} \mathrm{Ra}$ and ${ }^{232} \mathrm{Th}$ activity concentrations in soil are not unexpected.

Discriminant Analysis, as a multivariate test of differences among groups of surface soil sampling sites -South, Center, North- based on the measured ${ }^{226} \mathrm{Ra}$, ${ }^{232} \mathrm{Th},{ }^{4} \mathrm{~K}$ and ${ }^{137} \mathrm{Cs}$ activity concentrations, showed $76.6 \%$ of original grouped cases as correctly classified. Soil samples from three regions in Montenegro (group centroids) were found to be clearly separated by two discriminant functions.

Principal Component Analysis with radionuclide activity concentrations, radium equivalent activity, external and internal hazard index, activity concentration index, gamma absorbed dose rate in air and annual effective dose - all serving as variables, extracted two components explaining around $92.8 \%$ of the total variance.

\section{REFERENCES}

1. Statistical Yearbook of Montenegro 2018, Statistical Office of Montenegro - MONSTAT, Podgorica, Montenegro, 2018.

Retrieved from:

http://monstat.org/userfiles/file/publikacije/godisnjak \%202018/GODISNJAK\%202018\%20PRELOM.pdf Retrieved on: Sep. 26, 2019

2. N. M. Antovic, N. Svrkota, I. Antovic, "Radiological impacts of natural radioactivity from soil in Montenegro," Radiat. Prot. Dosim., vol. 148, no. 3, pp. $310-317$, Feb. 2012.

DOI: $10.1093 / \mathrm{rpd} / \mathrm{ncro} 87$ PMid: 21498861

3. N. M. Antović, D. S. Bošković, N. R. Svrkota, I. M. Antović, "Radioactivity in soil from Mojkovac, Montenegro, and assessment of radiological and cancer risk," Nucl. Technol. Radiat. Prot., vol. 27, no. 1, pp. 57-63, Mar. 2012. DOI: $10.2298 / \mathrm{NTRP} 1201057 \mathrm{~A}$

4. N. M. Antović et al., "Radioactivity impact assessment of Nikšić region in Montenegro," J. Radioanal. Nucl. Chem., vol. 302, no. 2, pp. $831-836$, Nov. 2014. DOI: $10.1007 / \mathrm{s} 10967-014-3254-3$
5. N. M. Antovic, P. Vukotic, N. Svrkota, S. K. Andrukhovich, "Pu-239+240 and $\mathrm{Cs}-137$ in Montenegro soil: their correlation and origin," J. Environ. Radioact., vol. 110, pp. 90 - 97, Aug. 2012. DOI: 10.1016/j.jenvrad.2012.02.001 PMid: 22445877

6. Sources and Effects of Ionizing Radiation, Annex B, Rep. A/55/46, UNSCEAR, New York (NY), USA, 2000. Retrieved from: https://www.unscear.org/docs/publications/2000/UN SCEAR 2000 Annex-B.pdf

Retrieved on: Jun. 25, 2016

7. Sources and Effects of Ionizing Radiation, Annex B, Rep. A/63/46, UNSCEAR, New York (NY), USA, 2010. Retrieved from: https://www.unscear.org/docs/publications/2008/UN SCEAR 2008 Annex-B-CORR.pdf Retrieved on: Feb. 10, 2019

8. Environmental Measurements Laboratory (EML) Procedures Manual, Rep. HASL-30o, U.S. Department of Homeland Security, New York (NY), USA, 1997.

Retrieved from: https://www.hsdl.org/?abstract\&did=487142 Retrieved on: Apr. 2, 2019

9. GammaVision-32 Software User's Manual, 6th ed., AMETEK Inc. (ORTEC), Oak Ridge (TN), USA, 2003.

Retrieved from:

https://www.ortec-online.com/$\lfloor$ media/ametekortec/manuals/a66-mnl.pdf Retrieved on: Feb. 10, 2019

10. Recommended data, Laboratoire National Henri Becquerel, Gif-Sur-Yvette, France, 2017. Retrieved from: http://www.nucleide.org/DDEP WG/DDEPdata.htm Retrieved on: Nov. 09, 2018

11. J. Beretka, P. J. Matthew, "Natural radioactivity of Australian building materials, industrial wastes and by-products," Health Phys., vol. 48, no. 1, pp. $87-95$, Jan. 1985.

DOI: 10.1097/00004032-198501000-00007 PMid: 3967976

12. The Council of European Union. (Dec. 5, 2013). Council Directive 2013/59/EURATOM. Laying down basic safety standards for protection against the dangers arising from exposure to ionising radiation, and repealing Directives 89/618/Euratom, 90/641/Euratom, 96/29/Euratom, 97/43/Euratom and 2003/122/Euratom.

Retrieved from:

https://eur-

lex.europa.eu/LexUriServ/LexUriServ.do?uri=OJ:L:20 14:013:0001:0073:EN:PDF

Retrieved on: Jul. 11, 2019

13. SPSS Statistics version 20, IBM, Armonk (NY), USA, 2011.

Retrieved from:

https://www.ibm.com/support/pages/ibm-spssstatistics-200-release-notes\#relnotes description Retrieved on: Aug. 29, 2019

14. N. M. Antovic, N. Svrkota, I. Antovic, R. Svrkota, D. Jancic, "Radioactivity in Montenegro beach sands and assessment of the corresponding environmental risk," Isot. Environ. Health Stud., vol. 49, no. 2, pp. $153-162$, Jun. 2013.

DOI: $10.1080 / 10256016.2013 .734303$ PMid: 23452289

15. M. Mirković i dr., "Geološka karta Crne Gore, 1:200.00o," Zavod za geološka istraživanja Crne Gore, Podgorica, Crna Gora, 1985.

(M. Mirković et al., "Geological Map of Montenegro, 1:200,000," Geological Survey of Montenegro, Podgorica, Montenegro, 1985.)

Retrieved from: https://geozavod.co.me/

Retrieved on: Jun. 29, 2019 